\title{
Flood mitigation study on a GIS platform for an ungauged catchment: a case study
}

\author{
A. K. Gopinath ${ }^{1} \&$ T. Radhakrishnan ${ }^{2}$ \\ ${ }^{1}$ Water Resources Dept, Govt. of Kerala, India \\ ${ }^{2}$ Indian Institute of Information Technology and Management, \\ Govt. of Kerala, India
}

\begin{abstract}
Uninstrumented watersheds pose a problem to the practising engineers when attempts to mitigate the flood waters of these watersheds are taken up. The problems become complex when one encounters a situation where there is no demarcation available for the watersheds in a region, nor historic data available for any meteorological factors of the region. Practising engineers usually adopt unscientific rational or empirical methods for estimating the design flood. But these approaches lead to overestimation or under estimation of floods, since such approaches do not take into account the hydro-meteorological factors of the watershed under consideration. Hence a more scientific approach for flood estimation is required for a cost effective design of the stream networks. This aspect is taken up through this study. The case study pertains to mitigation of flood waters in the Onattukara region of Kerala State, India which encompasses all these complexities. Twelve micro watersheds in this region were identified and this was made possible through identification of drainage networks in the area and digitization of the same on GIS platform. A scientific approach which takes into account all the above mentioned factors for ungauged catchments and developed by Central Water Commission (CWC), Govt of India was applied for this region. To bring out the effectiveness of this method, a comparison of this method with the conventional method on estimation of flood discharge is made. The flood discharge values are estimated with the existing empirical and rational formulae (Conventional method) for this region. The comparison with that obtained from the CWC model has considerable deviation.

Keywords: uninstrumented watershed, rational and empirical formulae, central water commission (CWC), drainage, geographical information system (GIS).
\end{abstract}




\section{Introduction}

Design flood estimation for an ungauged catchment includes empirical and scientific procedures. The empirical procedures used presently by field engineers for small watersheds up to $75 \mathrm{sq} . \mathrm{km}$ have liberal approximations, assumptions, no frequency concept and over simplification, thereby leading to over estimation or under estimation of the estimated design flood. On the other hand, the scientific procedures take in to account the hydro-meteorological factors and geographic factors of the watershed under consideration. The CWC model [1] uses scientific procedures in estimation of design flood for ungauged catchment in India for small watersheds for a specific return period. Under the long term plan CWC has divided India into 26 hydro-meteorologically homogeneous sub- zones. An improved estimation using the CWC model suitable for small watersheds and the empirical procedures are applied to estimate design flood of a selected region in Kerala State, India. The estimates of flood by these methods are compared by keeping CWC model as the standard and the percentage deviation of the empirical methods from CWC model are brought out.

\section{Study area}

Kerala State is a small strip of land lying at the south-west corner of India. It lies to the north of the equator between $8^{\circ} 18^{\prime}$ and $12^{\circ} 48^{\prime}$ north latitude and $74^{\circ} 52^{\prime}$ and $77^{\circ} 24^{\prime}$ east longitude. Kerala State extends over an area of 38,863 sq.km which is only 1.03 percent of the total area of India. The Onattukara region in Kerala State lies between Achencoil River in the north and Pallikal River in the south. The geographical extent of the region is between $9^{\circ} 20^{\prime}$ and $9^{\circ} 50^{\prime}$ North Latitude and $76^{\circ} 22^{\prime}$ and $76^{\circ} 45^{\prime}$ east longitude. The areal extent of this region is $23653 \mathrm{ha}$, and is one of the major agro climatic zones in Kerala State, India. This region was once the granary of the erstwhile Kayankulam dynasty of Kerala state having a paddy cultivable area of 6090 ha. Physiographic divisions of Kerala, India (Fig. 1).

The present agriculture practice is in a dilapidated condition, mainly due to flooding caused because of the pathetic state of the streams and ponds in this region. These water systems were catering to the needs of the paddy cultivation without any artificial means of irrigation. Due to fear of flooding, Onattukara paddy fields have been subjected to tremendous changes in land use, like coconut, areca nut, pepper, rubber, mixed crops, banana, tapioca, vegetables, built up land etc replacing paddy. Besides, large areas of the paddy fields are kept as fallow land.

Lack of proper planning and development of the hydrological networks is one of the main reasons for the pathetic state of the streams and channels in the region. But when one attempts the design of the carrying capacity of streams and channels in this region the problems faced are numerous and they are as follows. The watersheds in this region are not demarcated and there is no historic data available for the meteorological factors of the region. The streams in the region are also ungauged. The carrying capacity of the streams and channels can be 


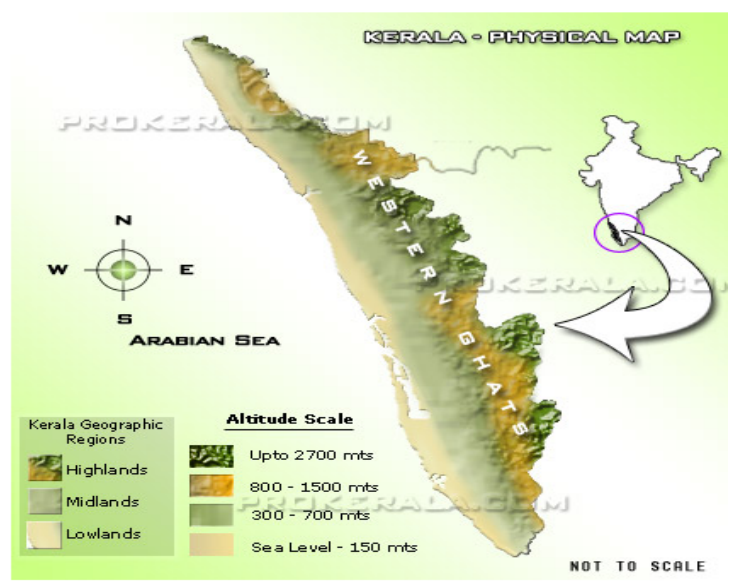

Figure 1: Physiographic divisions of Kerala.

designed only if the design flood of the region is properly estimated. Hence all the problems mentioned above have to be solved effectively to estimate the design flood of the region satisfactorily.

\section{Drainage characteristics of the region}

The water flow characteristics of Onattukara region are very unique. The Kayankulam - Punalur road (K-P road) is the water shed divide between north and south in Onattukara region. The flow pattern of the region is from north to south direction below the K-P road and from south to north for watersheds above K-P road. Twelve watersheds have been identified and demarcated in the study area. The details of these watersheds are given below.

a) Water sheds identified below K-P road in the Onattukara region and flowing to the Pallickal river are as follows

i) Puvattur water shed, ii) Vallikunnam water shed, iii) Puduchira water shed, iv) T-A Canal south water shed

b) The water sheds north of K-P road in the Onattukara region and flowing through TA canal into the Achencoil river

i) Vettikodu watershed, ii) Ammancheri watershed, iii) Thazhavazhil watershed, iv) T-A canal north watershed

c) Watersheds flowing directly to the Achencoil river

i) Thazhakara watershed, ii) Perivelilchal watershed, iii) Karingalilchal water shed

d) Watershed draining into the Kayankulam estuary

i) Karipuzha watershed which includes (Karipuzha main canal, Karipuzha sub:1, Karipuzha sub:2 and Karipuzha sub:3) 


\section{Theoretical background}

Practising engineers in Kerala earlier adopted empirical methods (Jaya Rami Reddy [2], Varshney [3], Raghunath [4]) for estimating the design floods for small watersheds. But these empirical approaches lead to an overestimation or underestimation of floods, since such approaches do not take into account the meteorological, hydrologic and geographic factors of the watershed under consideration.

A model developed by the Central Water Commission (CWC model), Govt of India for ungauged catchments for specific return periods is a scientific approach for estimation of design flood. The CWC model, as well as empirical methods, were used in estimating the design flood for the Onattukara region in the present study.

\subsection{Empirical formulae}

The empirical formulae commonly used by practicing engineers in Kerala were applied to the basin under study for estimating design flood of the 12 watersheds in the basin.

Table 1: $\quad$ Empirical formulae commonly used in the Kerala region.

\begin{tabular}{|c|c|c|c|}
\hline $\begin{array}{l}\text { Sl. } \\
\text { No }\end{array}$ & $\begin{array}{l}\text { Empirical } \\
\text { formulae }\end{array}$ & Equation & Remarks \\
\hline 1 & $\begin{array}{c}\text { Dicken's } \\
\text { formula: } \\
\text { (Based on Area) }\end{array}$ & $\mathrm{Q}=\mathrm{CA}^{3 / 4}$ & $\begin{array}{l}\text { Catchment co- } \\
\text { efficient } \mathrm{C} \text { adopted } \\
\text { for Kerala region, } \\
\text { India is } 22.2 \text { to } 25.0\end{array}$ \\
\hline 2 & $\begin{array}{c}\text { Ryve's } \\
\text { formulae: } \\
\text { (Based on Area) }\end{array}$ & $\mathrm{Q}=\mathrm{CA}^{2 / 3}$ & $\begin{array}{c}\text { C may be adopted as } \\
\text { follows } \\
\text { Areas within } 80 \mathrm{~km} \\
\text { from coast: } 6.75 \\
\text { Areas within } 80 \text { to } \\
2400 \mathrm{Km} \text { from coast: } \\
8.45 \\
\text { Limited areas near } \\
\text { hills }: 10.00\end{array}$ \\
\hline 3 & $\begin{array}{c}\text { Fuller's } \\
\text { formulae } \\
\text { (Based on Area } \\
\text { and recurrence } \\
\text { interval) }\end{array}$ & $\begin{array}{c}\mathrm{Q}_{\mathrm{av}}=\mathrm{CA}^{0.8} \\
\mathrm{Q}=\mathrm{Q}_{\mathrm{av}}\left(1+0.8 \log \mathrm{T}_{\mathrm{r}}\right) \\
\mathrm{Q}_{\max }=\mathrm{Q}\left(1+2.66 \mathrm{~A}^{-0.3}\right)\end{array}$ & $\begin{array}{l}\mathrm{Q} \text { is the flood } \\
\text { discharge in } \mathrm{m}^{3} / \mathrm{sec} \\
\text { per Sq. } \mathrm{km} \text { with a } \\
\text { return period of } \mathrm{T}_{\mathrm{r}} \\
\text { years, } \mathrm{A} \text { is the } \\
\text { drainage area in } \\
\text { Sq. Km } \\
\mathrm{C}=0.026 \text { to } 2.77\end{array}$ \\
\hline
\end{tabular}




\subsection{Central water commission (CWC) model}

Onattukara watersheds are ungauged watersheds. No reliable historic rainfall or discharge data is available for this region. Under these circumstances assessment of flood discharge of each catchment is very cumbersome and some hydrologic techniques have to be adopted to get reliable hydro-meteorological information for each catchment. Central Water Commission, Govt of India has adopted a regional approach for flood estimation which takes in to consideration the hydrometeorological factors also.

\subsubsection{Steps involved in estimation of design flood}

1. Preparation of the catchment area plan of the ungauged catchment under consideration

The methodology involved the accomplishment of the following tasks.

- Preparation of Drainage Network and Digital elevation model

- Watershed Delineation/Catchment area estimation

- Estimation of length of the drainage in each watershed

- Estimation of area/perimeter of ponds/reservoirs

- Watershed centroid Identification

- Estimation of the distance from the outlet point of the drainage system to the centroid.

For this, the drainage network of the region is digitized as shape files (Coordinate system-Geographic datum-WGS84) from the topographic maps using the Arc Map module of Arc GIS Ver9.2. The digital elevation model is downloaded from ASTER (Advanced space borne thermal emission and reflection radiometer) NASA, USA satellite having a resolution of $30 \mathrm{mX} 30 \mathrm{~m}$ to obtain elevation data on a near globe scale to generate the most complete high resolution digital topographic data base of earth. The DEM data, pertaining to the specified region is loaded on an ARC Map and the desired area is clipped with the boundary shape file of the region using spatial analyst module of Arc GIS as given in Fig. 2. By referring to the DEM, Drainage Network and topographic maps, the watershed boundary of each drainage stream is digitized as polygons as given in Fig. 3 .

2. The physiographic parameters like the area of watershed, Length of the longest stream is determined using Gvsig.BETA :2 version open source GIS software. Based on the regionalized equations applicable for this region in the CWC model given in Table 2 and using the values of physiographic parameters the Synthetic unit hydrograph ordinates are determined i.e. $\mathrm{q}_{\mathrm{p}}, \mathrm{Q}_{\mathrm{p}}, \mathrm{t}_{\mathrm{p}}, \mathrm{T}_{\mathrm{m}}, \mathrm{W}_{50}, \mathrm{~W}_{75}$, $\mathrm{WR}_{50}, \mathrm{WR}_{75}$, and $\mathrm{T}_{\mathrm{B}}$ and the entire details are given in Table 3.

3. From the above data, the synthetic unit hydrograph of each watershed is generated. A typical synthetic unit hydrograph for two major catchments i.e. Karingalilchal and Peruvelilchal watersheds are shown in Fig. 4.

4. The design storm duration $T_{D}$, which causes the maximum discharge in a drainage basin is estimated using the CWC model as $1.1^{*} \mathrm{t}_{\mathrm{p}, \text { It }}$ is suggested in the CWC model to consider the higher value $\mathrm{T}_{\mathrm{D}}$, between $\mathrm{T}_{\mathrm{D}}=1.1^{*} \mathrm{t}_{\mathrm{p}}$ and $\mathrm{T}_{\mathrm{D}}=\mathrm{T}_{\mathrm{B}}$. 


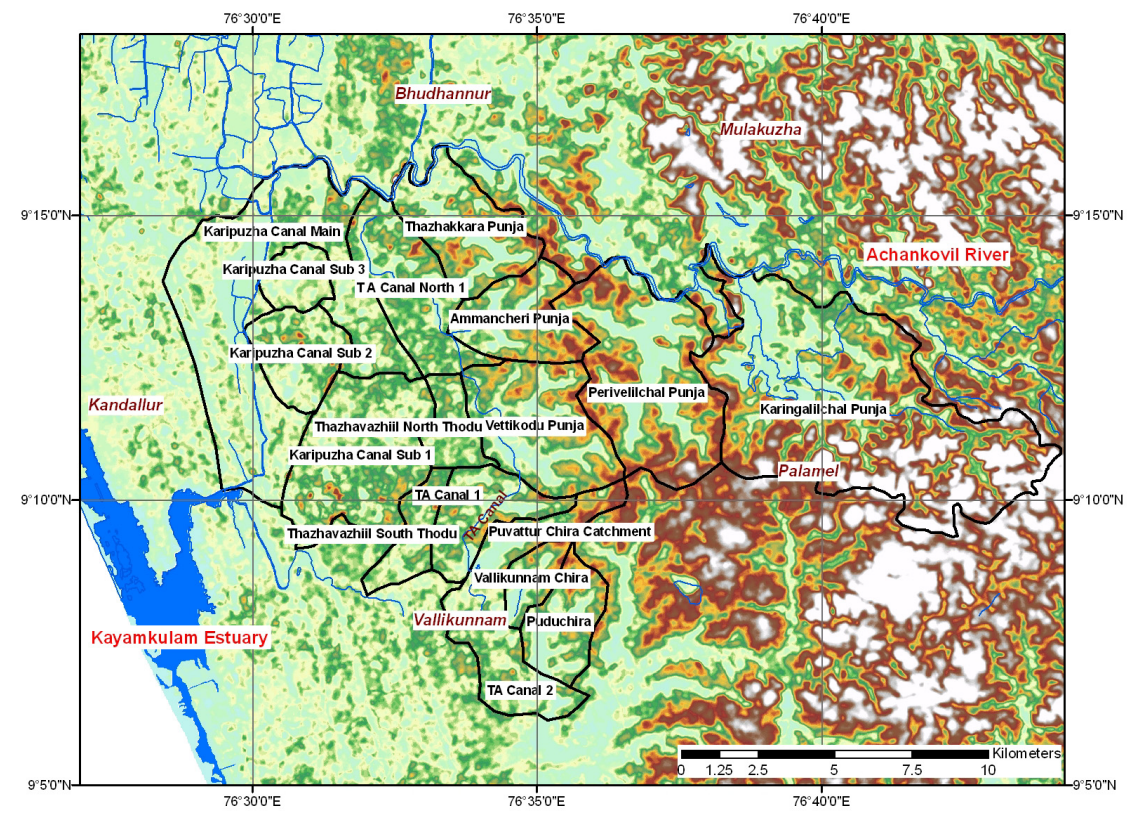

Figure 2: Digital elevation model for the Onattukara region.

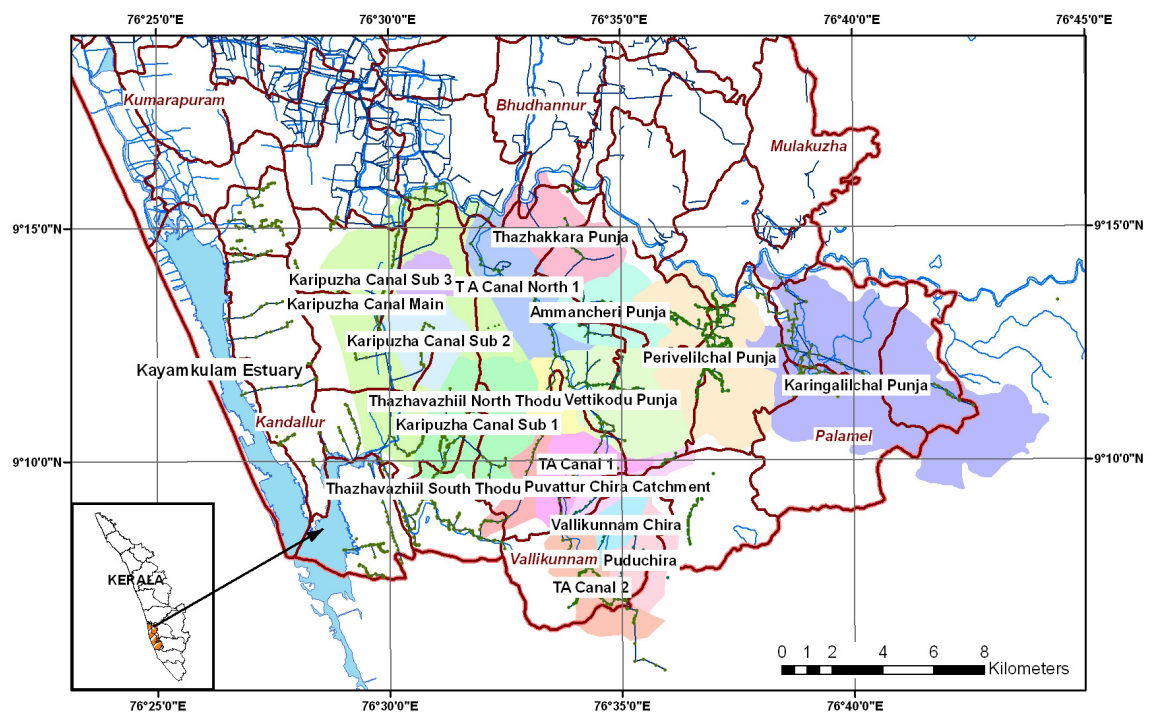

Figure 3: Demarcated 12 watersheds in the Onattukara region.

5. For the catchment under study, the $25 \mathrm{yr}-24 \mathrm{hr}$ point rainfall is obtained from the isopluvial maps generated by IMD (Indian Meteorological department) and is $20 \mathrm{~cm}$. 
Table 2: $\quad$ CWC model synthetic unit hydrograph parameters for the Kerala region.

\begin{tabular}{|c|c|c|}
\hline Sl. No & Equation & Remarks \\
\hline 1 & $\mathrm{q}_{\mathrm{p}}=0.9178(\mathrm{~L} / \mathrm{S})^{-0.4313}$ & $\begin{array}{l}\mathrm{q}_{\mathrm{p}}=\text { Peak discharge of unit hydrograph per unit } \\
\text { area in cumecs per sq.km, l= length of the } \\
\text { longest main stream along the river course in } \\
\mathrm{km}, \mathrm{S}=\text { Equivalent stream slope in } \mathrm{m} / \mathrm{km}\end{array}$ \\
\hline 2 & $\mathrm{t}_{\mathrm{p}}=\left(\mathrm{q}_{\mathrm{p}}\right)^{-1.0814}$ & $\begin{array}{l}\mathrm{t}_{\mathrm{p}}=\text { time from the centre of unit rainfall } \\
\text { duration to the peak of unit hydrograph in } \\
\text { hours }\end{array}$ \\
\hline 3 & $\mathrm{~W}_{50}=1.925\left(\mathrm{q}_{\mathrm{p}}\right)^{-1.0896}$ & $\begin{array}{l}\mathrm{W}_{50}=\text { width of the U.G measured at 50percent } \\
\text { peak discharge ordinate }\left(\mathrm{Q}_{\mathrm{p}}\right) \text { in hours }\end{array}$ \\
\hline 4 & $\mathrm{~W}_{75}=1.0189\left(\mathrm{q}_{\mathrm{p}}\right)^{-1.0443}$ & $\begin{array}{l}\mathrm{W}_{75}=\text { width of the U.G measured at } 75 \text { percent } \\
\text { peak discharge ordinate }\left(\mathrm{Q}_{\mathrm{p})} \text { in hours }\right.\end{array}$ \\
\hline 5 & $\begin{array}{l}\mathrm{W}_{\mathrm{R} 50}=0.5788\left(\mathrm{q}_{\mathrm{p}}\right)^{-} \\
1.1072\end{array}$ & $\begin{array}{l}\mathrm{W}_{\mathrm{R} 50}=\text { width of the rising side of U.G } \\
\text { measured at 50percent peak discharge ordinate } \\
\left(\mathrm{Q}_{\mathrm{p})} \text { in hours }\right.\end{array}$ \\
\hline 6 & $\underbrace{\mathrm{W}_{\mathrm{R} 75}}_{1.0538}=0.3469\left(\mathrm{q}_{\mathrm{p}}\right)^{-}$ & $\begin{array}{l}\mathrm{W}_{\mathrm{R} 75}=\text { width of the rising side of U.G } \\
\text { measured at } 75 \text { percent peak discharge ordinate } \\
\left(\mathrm{Q}_{\mathrm{p})} \text { in hours }\right.\end{array}$ \\
\hline 7 & $\mathrm{~T}_{\mathrm{B}}=7.380\left(\mathrm{t}_{\mathrm{p}}\right)^{0.7343}$ & $\mathrm{~T}_{\mathrm{B}}$-Base width of unit hydrograph in hours \\
\hline 8 & $\mathrm{t}_{\mathrm{m}}=\mathrm{t}_{\mathrm{p}}+\mathrm{t}_{\mathrm{r}} / 2$ & $\begin{array}{l}t_{m} \text {-Time from the start of the rise to the peak } \\
\text { of unit hydrograph in hours }\end{array}$ \\
\hline 9 & $\mathrm{Q}_{\mathrm{p}}=\mathrm{q}_{\mathrm{p}} \times \mathrm{A}$ & $\begin{array}{l}\mathrm{Q}_{\mathrm{p}} \text { - Peak discharge of unit hydrograph in } \\
\text { cubic meter per second }\end{array}$ \\
\hline
\end{tabular}

6. The $25 \mathrm{yr}-24 \mathrm{hr}$ point rainfall is converted to $25 \mathrm{yr}-\mathrm{T}_{\mathrm{D}} \mathrm{hr}$ point rainfall. The conversion ratio for various durations is as follows

7. The point rainfall for different durations $1,3,6,12, \ldots, 24 \mathrm{hrs}$ are converted into areal rainfall and the corresponding areal reduction factor (ARF) for different durations as given in the CWC model (Appendix 1) is used in the study and the rainfall value suitable adjusted.

$\begin{array}{cc}\text { Duration in hrs } \mathrm{T}_{\mathrm{D}} & \text { Ratio } \\ 1 & 0.32 \\ 3 & 0.48 \\ 6 & 0.61 \\ 9 & 0.70 \\ 12 & 0.78 \\ 15 & 0.85 \\ 18 & 0.91 \\ 24 & 1.00\end{array}$



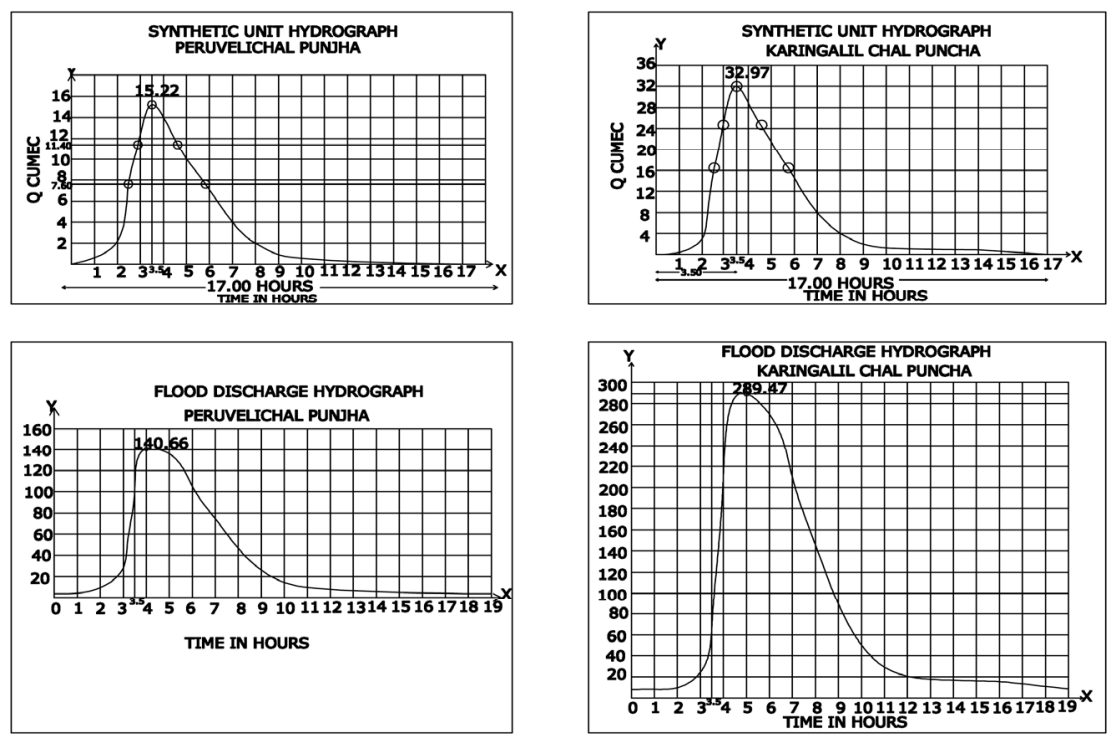

Figure 4: Synthetic unit hydrograph and flood hydrograph for Karingalilchal and Peruvelilchal watersheds.

8. Corresponding to the estimated design storm duration $T_{D}$, the rainfall depths at 1-hr interval is obtained by multiplying the rainfall values with time distribution co-efficient given in (Appendix 2).

9. The 1- hr areal rainfall increments is obtained by subtracting the successive 1-hr cumulative values of rainfall obtained in step-8.

10. One hour effective rainfall increments is obtained by subtracting the design loss rate of $0.19 \mathrm{~cm} / \mathrm{hr}$ from one hour areal rainfall increment. The loss rate of $0.19 \mathrm{~cm} / \mathrm{hr}$ is recommended in CWC model for this region.

11. Reverse the sequence of effective rainfall units obtained in step 10 to get the critical sequence of the effective rainfall.

12. Multiply the first $1-\mathrm{hr}$ effective rainfall with the ordinate of the synthetic unit hydrograph to get the corresponding direct runoff ordinates. Like wise repeat the procedure with the rest of the hourly effective rainfall values giving a lag of 1-hr to successive direct runoff ordinates.

13. Add the direct runoff ordinates at $1-\mathrm{hr}$ interval to get the total direct runoff hydrograph.

14. Finally the base flow of 0.15 cumecs/Sq.Km suggested in the CWC model is added to the direct runoff ordinates at 1-hr interval obtained in step 13 to get the $25 \mathrm{yr}$ flood hydrograph recommended for flood mitigation studies in agricultural catchments. The base flow recommended is based on analysis of 111 flood events and is found to generally lie in the range of $0.135-0.185 \mathrm{cumec} / \mathrm{Sq} . \mathrm{Km}$. 15. The design flood obtained based on the above procedure for 12 watersheds of Onattukara region is also given in Table 3. 


\begin{tabular}{|c|c|c|c|c|c|c|c|c|c|c|c|c|}
\hline 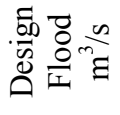 & ஸ̃ & 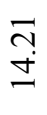 & 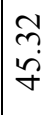 & $\begin{array}{l}\hat{b} \\
\text { ते }\end{array}$ & \begin{tabular}{l}
\multirow{2}{\infty}{} \\
$\stackrel{+}{+}$
\end{tabular} & $\left|\begin{array}{l}n \\
n \\
\dot{q} \\
\dot{y}\end{array}\right|$ & $\frac{n}{\stackrel{n}{n}}$ & $\vec{\sim}$ & $\begin{array}{l}\infty \\
\\
=\end{array}$ & $\stackrel{\sim}{\dot{q}}$ & مें & $\begin{array}{l}\infty \\
\infty \\
0 \\
2\end{array}$ \\
\hline$\tilde{\partial}^{m}$ & $\stackrel{\Xi}{\sigma}$ & فे & $\begin{array}{l}\infty \\
\infty \\
\dot{\forall}\end{array}$ & Ii & $\begin{array}{l}\dot{+} \\
\forall\end{array}$ & $\mid \begin{array}{l}\stackrel{R}{2} \\
\dot{m}\end{array}$ & $\begin{array}{l}\infty \\
\infty \\
\dot{n}\end{array}$ & $\frac{⿱ 亠}{\sim}$ & 导 & $\stackrel{n}{n}$ & กิ & $\left|\begin{array}{l}\infty \\
\infty \\
0\end{array}\right|$ \\
\hline$\Xi \exists$ & $\tilde{n}$ & $\stackrel{\circ}{\forall}$ & $\ddot{n}$ & 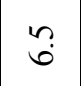 & $\tilde{6}$ & $\begin{array}{l}n \\
n \\
n\end{array}$ & 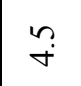 & $n$ & $\because$ & $n$ & 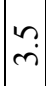 & $\stackrel{n}{0}$ \\
\hline$\stackrel{\oplus}{\oplus}$ & $\stackrel{n}{\check{c}}$ & $\stackrel{\circ}{9}$ & $\stackrel{n}{\simeq}$ & $\stackrel{\circ}{\infty}$ & 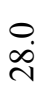 & 吕 & $\stackrel{n}{n}$ & 이 & ? & $\begin{array}{l}0 \\
-1 \\
-1\end{array}$ & $\stackrel{0}{0}$ & Oे \\
\hline 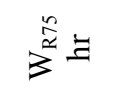 & $\stackrel{m}{\circ}$ & $\stackrel{\infty}{\stackrel{\infty}{0}}$ & n़े & $\stackrel{n}{n}$ & $\hat{n}$ & $\stackrel{N}{\stackrel{2}{-}}$ & $\stackrel{\infty}{n}$ & $\stackrel{8}{\circ}$ & $\because$ & ํ. & $\begin{array}{l}\infty \\
\vdots \\
0\end{array}$ & ri \\
\hline$\sum^{\frac{2}{3}}=$ & $\stackrel{N}{0}$ & $\stackrel{\text { m}}{-}$ & $\begin{array}{l}0 \\
0 \\
0\end{array}$ & ָे & กิ & $\stackrel{0}{0}$ & $\begin{array}{l}\infty \\
0 \\
0\end{array}$ & $\mid \begin{array}{l}0 \\
0 \\
0 \\
0\end{array}$ & 吕 & $\begin{array}{l}\overline{6} \\
\dot{0}\end{array}$ & ñ & ì \\
\hline $3^{2}=$ & $\stackrel{n}{\sim}$ & $\frac{a}{i}$ & $\stackrel{n}{=}$ & $\begin{array}{l}\infty \\
\dot{\sigma} \\
\dot{m}\end{array}$ & $\stackrel{m}{\stackrel{m}{r}}$ & $\mid$ & $\stackrel{\sim}{\sim}$ & $\underline{-}$ & $\mid \begin{array}{l}\infty \\
\infty \\
0\end{array}$ & $\stackrel{m}{2}$ & $\underline{6}$ & â \\
\hline $3^{n} \exists$ & $\begin{array}{l}\infty \\
n \\
\sim\end{array}$ & ָั & $\frac{\infty}{2}$ & $\stackrel{n}{n}$ & $\stackrel{n}{r}$ & $\begin{array}{l}\tilde{\sigma} \\
\dot{r} \\
\end{array}$ & $\stackrel{+}{*}$ & $\vec{m}$ & 官 & $\begin{array}{l}n \\
n \\
m\end{array}$ & 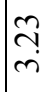 & ב̃ \\
\hline \begin{tabular}{l}
$\exists$ \\
\multirow{2}{*}{}
\end{tabular} & $\stackrel{0}{0}$ & $\ddot{n}$ & $\begin{array}{l}0 \\
i\end{array}$ & 우 & $\stackrel{0}{0}$ & $\begin{array}{l}0 \\
\dot{1}\end{array}$ & $\stackrel{\circ}{+}$ & $\begin{array}{c}8 \\
\dot{0}\end{array}$ & $\begin{array}{l}8 \\
\text { i }\end{array}$ & $\begin{array}{c}8 \\
\vdots \\
\dot{m}\end{array}$ & $\begin{array}{l}8 \\
\dot{0} \\
\dot{m}\end{array}$ & $\begin{array}{l}0 \\
0 \\
0\end{array}$ \\
\hline$=\frac{y}{\ddot{\Phi}} \Xi$ & $\begin{array}{c}\sigma \\
0 \\
0\end{array}$ & $\stackrel{\infty}{+}$ & $\begin{array}{l}2 \\
\infty \\
0\end{array}$ & ฮิ & กิ & $\hat{n}$ & to & $\begin{array}{l}\vec{b} \\
\dot{0}\end{array}$ & $\stackrel{n}{=}$ & $\begin{array}{c}\sigma \\
6 \\
0\end{array}$ & $\begin{array}{l}\mathcal{\sigma} \\
0\end{array}$ & $\frac{\infty}{0}$ \\
\hline$\backsim \underset{\Xi}{\Xi}$ & $\frac{9}{i}$ & $\stackrel{テ}{\circ}$ & $\stackrel{m}{r}$ & ๙ু & กี & $n$ & $\stackrel{\nabla}{-}$ & さ્さ & $\begin{array}{l}6 \\
6 \\
n\end{array}$ & $\begin{array}{l}\hat{\sigma} \\
i\end{array}$ & $\stackrel{\infty}{\forall}$ & 文 \\
\hline$\stackrel{\mathcal{\Theta}}{ } \Xi$ & ๙n & $\ddot{n}$ & $\begin{array}{l}\overline{6} \\
i\end{array}$ & 守. & ஸे & 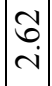 & $\begin{array}{l}\hat{\sigma} \\
\dot{+}\end{array}$ & $\stackrel{0}{\circ}$ & $\stackrel{m}{\sim}$ & $\begin{array}{c} \pm \\
\dot{m}\end{array}$ & $\hat{\sigma}$ & बे. \\
\hline తઘ & ñ & $\frac{\sim}{i}$ & $\begin{array}{l}\overrightarrow{6} \\
\dot{+}\end{array}$ & $\begin{array}{l}\dot{0} \\
\stackrel{\dot{\sigma}}{-}\end{array}$ & 它 & $\begin{array}{l}8 \\
\dot{+} \\
\end{array}$ & 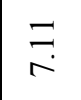 & ก̦ & $\begin{array}{l}0 \\
m \\
m\end{array}$ & $\frac{N}{2}$ & ヘָ & 尚 \\
\hline$\varangle^{N} \Xi$ & 察. & ñ & $\begin{array}{l}0 \\
+ \\
\text { in }\end{array}$ & $\begin{array}{l}0 \\
0 \\
I \\
\end{array}$ & $\begin{array}{l}\infty \\
0 \\
0\end{array}$ & $\begin{array}{l}2 \\
\infty \\
\vdots\end{array} \mid$ & $\stackrel{m}{i}$ & $\stackrel{\circ}{\circ}$ & $\begin{array}{l}\infty \\
\sim \\
\sim \\
\sim \\
-1\end{array}$ & $\begin{array}{l}0 \\
n \\
n \\
\sim \\
\end{array}$ & ๙̊ & 守. \\
\hline 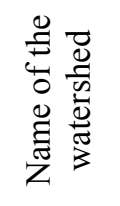 & 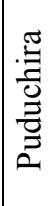 & 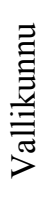 & 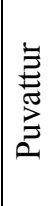 & 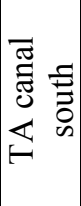 & $\begin{array}{l}\vec{z} \\
0 \\
\frac{y}{E} \\
\stackrel{0}{0}\end{array}$ & 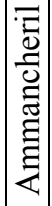 & 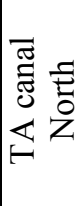 & 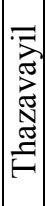 & 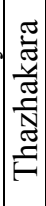 & $\begin{array}{l}= \\
:= \\
0 \\
2 \\
\overline{0} \\
2 \\
2\end{array}$ & 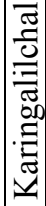 & 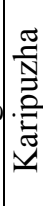 \\
\hline
\end{tabular}




\section{Design flood estimation using empirical formulae}

The design flood for 12 watersheds is also estimated by the empirical formulae commonly used in Kerala State with the CWC model and are given in Table 4.

Table 4: Design flood calculation using empirical formulae.

\begin{tabular}{|c|c|c|c|c|}
\hline $\begin{array}{c}\text { Name of } \\
\text { watershed }\end{array}$ & $\begin{array}{c}\text { Dicken's } \\
\text { formula } \\
\left(\mathrm{m}^{3} / \mathrm{sec}\right)\end{array}$ & $\begin{array}{c}\text { Ryve's } \\
\text { formula } \\
\left(\mathrm{m}^{3} / \mathrm{sec}\right)\end{array}$ & $\begin{array}{c}\text { Fuller's formula } \\
\left(\mathrm{m}^{3} / \mathrm{sec}\right)\end{array}$ & $\begin{array}{c}\text { CWC model } \\
\left(\mathrm{m}^{3} / \mathrm{sec}\right)\end{array}$ \\
\hline Puduchira & 103.82 & 25.73 & 36.34 & 54.27 \\
\hline Vallikunnu & 58.98 & 15.58 & 22.86 & 14.21 \\
\hline Puvattur & 82.15 & 20.91 & 29.94 & 45.32 \\
\hline TA canal south & 198.13 & 45.69 & 62.62 & 22.69 \\
\hline Vettikodu & 184.68 & 42.92 & 58.95 & 40.82 \\
\hline Ammancheril & 128.27 & 31.05 & 43.36 & 40.53 \\
\hline TA canal North & 155.0 & 36.74 & 50.80 & 54.15 \\
\hline Thazavayil & 71.06 & 18.38 & 26.59 & 23.7 \\
\hline Thazhakara & 150.83 & 35.23 & 51.74 & 117.8 \\
\hline Peruvelil & 259.44 & 56.93 & 78.98 & 140.9 \\
\hline Karingalilchal & 451.53 & 35.23 & 128.40 & 289.5 \\
\hline Karipuzha & 347.84 & 75.30 & 101.99 & 90.83 \\
\hline
\end{tabular}

Table 5: $\quad$ Percentage deviation of flood estimated.

\begin{tabular}{|c|c|c|c|}
\hline Name of watershed & $\begin{array}{c}\text { Dicken's } \\
\text { formula }\end{array}$ & $\begin{array}{c}\text { Ryve's } \\
\text { formula }\end{array}$ & $\begin{array}{c}\text { Fuller's } \\
\text { formula }\end{array}$ \\
\hline Puduchira & +91 & +53 & -33 \\
\hline Vallikunnu & +76 & -9.6 & +61 \\
\hline Puvattur & +81 & +54 & -34 \\
\hline TAcanal south & +773 & +101 & +175 \\
\hline Vettikodu & +352 & +5 & +44 \\
\hline Ammancheril & +217 & -23.3 & +6 \\
\hline TAcanal North & +186 & -32.5 & -6 \\
\hline Thazavayil & +199 & +22 & -12 \\
\hline Thazhakara & +28 & -70 & -56 \\
\hline Peruvelil & +84 & -59.5 & -44 \\
\hline Karingalilchal & +55 & -88 & -55 \\
\hline Karipuzha & +372 & -17 & +12.3 \\
\hline
\end{tabular}




\section{Error percentage estimation}

CWC model takes into consideration the hydro-meteorological aspects of the basin and is kept as standard for comparing the empirical formulae used by the practising engineers. The percentage deviation of the flood values obtained from empirical formulae from that of the CWC model are also brought out in Table 5.

\section{Conclusions}

The comparison of the CWC model with empirical methods based on the estimation of floods for 12 watersheds in the Onattukara region, Kerala State, India, clearly brings out that empirical methods are over or under estimating the design flood required for designing the carrying capacity of the streams to mitigate floods in small watersheds. This leads to the loss and destruction of structures or uneconomic structure with problematic situation. With the advancement in the field of open source free software for e.g. (Gvsig. BETA:2 version) and with free download satellite imagery from ASTER satellite, NASA, USA, estimation of design flood using the CWC model has become viable for the practicing engineers. Hence, regionalized hydro-meteorological models similar to the CWC model would play an important role in planning and designing water resource systems for long term flood mitigations in small ungauged catchments.

\section{Appendix 1: point to areal rainfall ratios (percentages) Sub zone 5(a and b)}

\begin{tabular}{|c|c|c|c|c|c|c|c|c|c|c|c|c|c|c|c|c|c|c|c|c|c|c|c|c|c|}
\hline $\begin{array}{l}\text { Area in } \\
\text { SQ.KM }\end{array}$ & 1 & 2 & 3 & 4 & 5 & 6 & 7 & 8 & 9 & 10 & 11 & 12 & 13 & 14 & 15 & 16 & 17 & 18 & 19 & 20 & 21 & 22 & 23 & 24 & $\begin{array}{l}\text { Area in } \\
\text { SQ.KM }\end{array}$ \\
\hline 0 & 100.00 & 100.00 & 100.00 & 100.00 & 100.00 & 100.00 & 100.00 & 100.00 & 100.00 & 100.00 & 100.00 & 100.00 & 100.00 & 100.00 & 100.00 & 100.00 & 100.00 & 100.00 & 100.00 & 100,00 & 100.00 & 100.00 & 100.00 & 100.00 & 0.00 \\
\hline 50 & 87.00 & 89.50 & 92.00 & 93.00 & 94.00 & 95.00 & 95.33 & 95.67 & 96.00 & 96.33 & 96.67 & 97.00 & 97.04 & 97.08 & 97.13 & 97.17 & 97.21 & 97.25 & 97.29 & 97.33 & 97.38 & 97.42 & 97.46 & 97.50 & 50.00 \\
\hline 100 & 81.00 & 84.50 & 88.00 & 89.00 & 90.00 & 91.00 & 91.50 & 92.00 & 92.50 & 93.00 & 93.50 & 94.00 & 94.04 & 94.08 & 94.13 & 94.17 & 94.21 & 94.25 & 94.29 & 94.33 & 94.38 & 94.42 & 94.46 & 94.50 & 100.00 \\
\hline 150 & 76.00 & 80.00 & 84.00 & 85.33 & 86.67 & 88.00 & 88.58 & 89.17 & 89.75 & 90,33 & 90.92 & 91.50 & 91.58 & 91.67 & 91.75 & 91.83 & 91.92 & 92.00 & 92.08 & 92.17 & 22.25 & 22.33 & 92.42 & 92.50 & 150.00 \\
\hline 200 & & & 80.50 & 82.17 & 83.83 & 85.50 & 86.08 & 86.67 & 87.25 & 87.83 & 88.42 & 89.00 & 89.17 & 89.33 & 89.50 & 89.67 & 89.83 & 90.00 & 90.17 & 90.33 & 90.50 & 90.67 & 90.83 & 91.00 & 200.00 \\
\hline 250 & & & 77.50 & 79.33 & 81.17 & 83.00 & 83.75 & 84.50 & 85.25 & 86.00 & 86.75 & 87.50 & 87.67 & 87.83 & 88.00 & 88.17 & $88.3 \hat{3}$ & 88.50 & 88.67 & 88.83 & 89.00 & 89.17 & 89.33 & 89.30 & 250.00 \\
\hline 300 & & & & & & 81.00 & 81.83 & 82.67 & 83.50 & 84.33 & 85.17 & 86.00 & 86.17 & 86.33 & 86.50 & 86.67 & 86.83 & 87.00 & 87.17 & 87.33 & 87.50 & 87.67 & 87.83 & 88.00 & 300.00 \\
\hline 350 & & & & & & 79.100 & 79.92 & 80.83 & 81.75 & 82.67 & 83.58 & 84.50 & 84.71 & 84.92 & 85.12 & 85.33 & 85.54 & 85.75 & $85 . \%$ & 86.17 & 86.38 & 86.58 & 86.79 & 87.100 & 350.0X] \\
\hline 400 & & & & & & 77.50 & 78.50 & 79.50 & 80.50 & 81.50 & 82.50 & 83.50 & 83.71 & 83.92 & 84.12 & 84.33 & 84.54 & 84.75 & 84.96 & 85.17 & 85.38 & 85.58 & 85.79 & 86.00 & 400.00 \\
\hline 450 & & & & & & 76.00 & 77.08 & 78.17 & 79.25 & 80.33 & 81.42 & 82.50 & 82.71 & 82.92 & 83.12 & 83.33 & 83.54 & 83.75 & 83.96 & 84.17 & 84.38 & 84.58 & 84.79 & 85.00 & 450.00 \\
\hline 500 & & & & & & 75.00 & 76.08 & 77.17 & 78.25 & 79.33 & 80.42 & 81.50 & 81.71 & 81.92 & 82.12 & 82.33 & 82.54 & 82.75 & 82.96 & 83.17 & 83.38 & 83.58 & 83.79 & 84.00 & 500.00 \\
\hline 600 & & & & & & & & & & & & 80.00 & 80.21 & 80.42 & 80.62 & 80.83 & 81.04 & 81.25 & 81.46 & 81.67 & 81.88 & 82.08 & 82.29 & 82.50 & 600.00 \\
\hline 700 & & & & & & & & & & & & 77.50 & 77.83 & 78.17 & 78.50 & 78.83 & 79.17 & 79.50 & 79.83 & 80.17 & 80.50 & 80.83 & 81.17 & 81.50 & 700.00 \\
\hline 800 & & & & & & & & & & & & 77.00 & 77.29 & 77.50 & 77.88 & 78.17 & 78.46 & 78.75 & 79.04 & 79.33 & 79.63 & 79.92 & 80.21 & 80.50 & 800.00 \\
\hline 900 & & & & & & & & & & & & 76.00 & 76.29 & 76.58 & 76.88 & 77.17 & 77.46 & 77.75 & 78.04 & 78.33 & 78.33 & 78.92 & 79.21 & 79.50 & 900.00 \\
\hline 1100 & & & & & & & & & & & & 75.00 & 75.29 & 75.58 & 75.88 & 76.17 & 76.46 & 76.75 & 77.04 & 77.33 & 77.63 & 77.92 & 78.21 & 78.00 & 1100.00 \\
\hline 1200 & & & & & & & & & & & & 7400 & 74.33 & 74.67 & 75.00 & 75.33 & 75.67 & 76.00 & 76.33 & 7667 & 77.00 & 77.33 & 77.67 & 77.50 & 1200.00 \\
\hline 1300 & & & & & & & & & & & & 73.00 & 73.38 & 73.75 & 74.13 & 74.50 & 74.88 & 75.25 & 75.63 & 76.00 & 76.38 & 76.75 & 77.13 & 7730 & 1300.00 \\
\hline 1400 & & & & & & & & & & & & & & & & & & & & & & & & 77.00 & 1400.00 \\
\hline 1500 & & & & & & & & & & & & & & & & & & & & & & & & 76.50 & 1500.00 \\
\hline 2000 & & & & & & & & & & & & & & & & & & & & & & & & 75.00 & 2000.00 \\
\hline 2500 & & & & & & & & & & & & & & & & & & & & & & & & 75.00 & 2500.00 \\
\hline
\end{tabular}




\section{Appendix 2: time distribution coefficient of areal rainfall}

\begin{tabular}{|c|c|c|c|c|c|c|c|c|c|c|c|c|c|c|c|c|c|c|c|c|c|c|c|c|}
\hline $\begin{array}{l}\text { Time } \\
\text { in hrs }\end{array}$ & 2 & 3 & 4 & 5 & 6 & 7 & 8 & 9 & 10 & 11 & 12 & 13 & 14 & 15 & 16 & 17 & 18 & 19 & 20 & 21 & 22 & 23 & 24 & $\begin{array}{l}\text { Time } \\
\text { in hrs }\end{array}$ \\
\hline 24 & & & & & & & & & & & & & & & & & & & & & & & 1.00 & 24 \\
\hline 23 & & & & & & & & & & & & & & & & & & & & & & 1.00 & 0.98 & 23 \\
\hline 22 & & & & & & & & & & & & & & & & & & & & & 1.00 & 0.98 & 0.96 & 22 \\
\hline 21 & & & & & & & & & & & & & & & & & & & & 1.00 & 0.98 & 0.96 & 0.94 & 21 \\
\hline 20 & & & & & & & & & & & & & & & & & & & 1.00 & 0,98 & 0.96 & 0.94 & 0.92 & 20 \\
\hline 19 & & & & & & & & & & & & & & & & & & 1.00 & 0.98 & 0.95 & 0.93 & 0.91 & 0.89 & 19 \\
\hline 18 & & & & & & & & & & & & & & & & & 1.00 & 0.98 & 0.95 & 0.93 & 0.91 & 0.89 & 0.87 & 18 \\
\hline 17 & & & & & & & & & & & & & & & & 1.00 & 0.98 & 0.95 & 0.92 & 0.90 & 0.88 & 0.86 & 0.84 & 17 \\
\hline 16 & & & & & & & & & & & & & & & 1.00 & 0.98 & 0.96 & 0.92 & 0.90 & 0.88 & 0.86 & 0.84 & 0.82 & 16 \\
\hline 15 & & & & & & & & & & & & & & 1.00 & 0.98 & 0.95 & 0.93 & 0.89 & 0.87 & 0.85 & 0.83 & 0.81 & 0.79 & 15 \\
\hline 14 & & & & & & & & & & & & & 1.00 & 0.97 & 0.95 & 0.93 & 0.91 & 0.86 & 0.84 & 0.82 & 0.80 & 0.78 & 0.76 & 14 \\
\hline 13 & & & & & & & & & & & & 1.00 & 0.97 & 0.95 & 0.92 & 0.90 & 0.88 & 0.83 & 0.81 & 0.79 & 0.77 & 0.76 & 0.74 & 13 \\
\hline 12 & & & & & & & & & & & 1.00 & 0.97 & 0.95 & 0.92 & 0.89 & 0.87 & 0.85 & 0.80 & 0.78 & 0.76 & 0.74 & 0.72 & 0.70 & 12 \\
\hline 11 & & & & & & & & & & 1.00 & 0.98 & 0.94 & 0.91 & 0.88 & 0.86 & 0.84 & 0.82 & 0.77 & 0.74 & 0.72 & 0.70 & 0.69 & 0.68 & 11 \\
\hline 10 & & & & & & & & & 1.00 & 0.97 & 0.95 & 0.90 & 0.87 & 0.85 & 0.83 & 0.81 & 0.78 & 0.73 & 0.71 & 0.69 & 0.67 & 0.65 & 0.64 & 10 \\
\hline 9 & & & & & & & & 1.00 & 0.97 & 0.94 & $0.91^{\circ}$ & 0.86 & 0.84 & 0.82 & 0.79 & 0.77 & 0.75 & 0.68 & 0.66 & 0.64 & 0.62 & 0.61 & 0.60 & 9 \\
\hline 8 & & & & & & & 1.00 & 0.97 & 0.95 & 0.90 & 0.87 & 0.82 & 0.79 & 0.77 & 0.75 & 0.73 & 0.70 & 0.64 & 0.63 & 0.60 & 0.58 & 0.57 & 0.55 & 8 \\
\hline 7 & & & & & & 1.00 & 0.96 & 0.92 & 0.89 & 0.85 & 0.82 & 0.77 & 0.75 & 0.73 & 0.70 & 0.68 & 0.65 & 0.60 & 0.58 & 0.56 & 0.54 & 0.53 & 0.51 & 7 \\
\hline 6 & & & & & 1.00 & 0.96 & 0.91 & 0.87 & 0.84 & 0.80 & 0.77 & 0.72 & 0.69 & 0.67 & 0.65 & 0.63 & 0.60 & 0.54 & 0.53 & 0.51 & 0.49 & 0.48 & 0.46 & 6 \\
\hline 5 & & & & 1.00 & 0.96 & 0.89 & 0.85 & 0.80 & 0.77 & 0.73 & 0.70 & 0.65 & 0.62 & 0.60 & 0.57 & 0.55 & 0.53 & 0.48 & 0.46 & 0.44 & 0.42 & 0.41 & 0.40 & 5 \\
\hline 4 & & & 1.00 & 0.95 & 0.90 & 0.82 & 0.77 & 0.72 & 0.69 & 0.65 & 0.62 & 0.57 & 0.54 & 0.52 & 0.50 & 0.48 & 0.45 & 0.41 & 0.40 & 0.38 & 0.36 & 0.35 & 0.34 & 4 \\
\hline 3 & & 1.00 & 0.94 & 0.87 & 0.81 & 0.71 & 0.66 & 0.62 & 0.59 & 0.55 & 0.51 & 0.47 & 0.44 & 0.42 & 0.40 & 0.38 & 0.35 & 0.33 & 0.32 & 0.30 & 0.29 & 0.28 & 0.27 & 3 \\
\hline 2 & 1.00 & 0.91 & 0.81 & 0.73 & 0.66 & 0.56 & 0.53 & 0.49 & 0.46 & 0.43 & 0.39 & 0.36 & 0.33 & 0.30 & 0.28 & 0.27 & 0.26 & 0.24 & 0.23 & 0.21 & 0.20 & 0.19 & 0.19 & 2 \\
\hline 1 & 0.82 & 0.68 & 0.57 & 0.50 & 0.45 & 0.36 & 0.31 & 0.30 & 0.28 & 0.26 & 0.24 & 0.19 & 0.18 & 0.17 & 0.16 & 0.15 & 0.13 & 0.12 & 0.12 & 0.12 & 0.11 & 0.10 & 0.10 & 1 \\
\hline
\end{tabular}

\section{References}

[1] Directorate of hydrology (Regional studies) Central water commission, Flood estimation report for west coast region Konakan and Malabar Coast, New Delhi, 1992.

[2] Jaya Rami Reddy P., A Text book of hydrology, Laxmi publications(pvt), Ltd, New Delhi, 1992

[3] Varshney R.S., Engineering hydrology, Nem cahnd \& bros publications, Roorkee, 1979.

[4] Raghunath H.M., Hydrology, Wiley eastern publications, New Delhi, 1985 